\title{
SIMPLE ADDITIVES TO INCREASE THE ACTIVITY OF CHLORHEXIDINE DIGLUCONATE AGAINST URINARY PATHOGENS ${ }^{\star}$
}

\author{
By W. E. S. HaRPER, M.Sc., E.I.L.M.S., M.A.S.M. \\ Department of Microbiology Royal Perth (Rehab.) Hospital, Shenton Park, Western \\ Australia.
}

\begin{abstract}
Summary. The concentration of chlorhexidine digluconate required to kill Gram-negative bacteria which cause urinary tract infection associated with urethral catheterisation also damages the bladder mucosa. Increased bactericidal activity was obtained by the addition of a chelating agent (EDTA) and a buffer (Tris) enabling a low concentration of chlorhexidine (O.O I per cent) to be effective against Escherichia coli NCTC 86, Pseudomonas aeruginosa NCTC 7650 Proteus mirabilis NCTC 8309 and Streptococcus faecalis NCTC 8213. The type of fluid in which the bacteria were suspended affected the time required to achieve 99.9 per cent killing. The 0.0 I per cent chlorhexidine solution with added EDTA and Tris did not cause severe erosive damage to the bladder mucosa of rats. The potential of this solution for use as a skin antiseptic prior to catheterisation and as a bladder instillation after catheterisation is discussed.
\end{abstract}

Key words: Urinary tract infection; Bladder irrigation; Antiseptics; Chlorhexidine digluconate.

\section{Introduction}

URINARY tract infection (UTI) is the most common nosocomial infection reported and the urethral catheter is the major single cause (Lindan, I972). Spinal injury patients who are being intermittently catheterised are therefore exposed to an increased risk of acquiring a bladder infection. The instillation of an antimicrobial solution prior to withdrawal of the catheter has been shown to reduce the incidence of bladder infection caused by catheterisation (Beeuweeks \& de Vries, I956; Gillespie et al., I962; Pearman, I97I, I977).

The selection of a bladder instillation solution for all species of bacteria commonly found in UTIs can prove to be difficult for a number of reasons. Recent studies of some bladder instillation solutions have been shown to have erosive side effects (Harper \& Matz, I976) and in the case of chlorhexidine there have been several reports of clinical haematuria (Paterson et al., 1960; Macfadyen \& Simmons, 1968; Pearman, 1971). Other solutions that have been used may only be effective against certain Gramnegative species which limits their overall cover for catheter induced infection.

This work was prompted by reports that EDTA could enhance the action of antiseptics (Brown \& Richards, 1965; Caplin \& Chapman, I976; Goldschmidt et al., I972) and that Tris increased the activity of EDTA

* Read at the Annual Scientific Meeting of the International Medical Society of Paraplegia, Athens, Greece. October 1982. 
(Voss, I 967; Goldschmidt and Wyss, I 967). It was hoped that the addition of these agents would enable the concentration of chlorhexidine to be reduced so that it was less erosive and also overcome any resistance that has been previously reported by Stickler (I974).

As urine has a high concentration of $\mathrm{Ca}^{++}$and $\mathrm{Mg}^{++}$it could inhibit the action of EDTA when used in the bladder. Consequently pooled urine has been compared with other vehicles to evaluate the potential in vivo effectiveness of chlorhexidine in combination with EDTA and EDTA/Tris. The test organisms used were Pseudomonas aeruginosa, Escherichia coli, Streptococcus faecalis, and Proteus mirabilis.

\section{Materials and Methods}

\section{Chemicals and Antiseptics}

Chlorhexidine digluconate (I-6-di (4-chlorophenyldiguanido -Hexane) ICI, Australia EDTA (Ethylenediamine tetraacetic acid-disodium salt) BDH, Poole England. Tris (2-Amino-2 Hydroxymethyl-Propane-I,3-Diol) BDH, Poole England.

\section{Media}

Blood-Agar base No. 2 (Oxoid Ltd., London).

Nutrient Agar base No. 2 (Oxoid Ltd., London).

Nutrient broth (Dehydrated Oxoid Ltd., London).

Lubrol broth (Bergan \& Hysted, I97I).

Minimal medium (Clowes \& Hayes, I 968).

\section{Bacterial Strains}

$\begin{array}{llr}\text { E. coli } & \text { NCTC } & 86 \\ \text { Ps. aeruginosa } & \text { NCTC } & 6750 \\ \text { P. mirabilis } & \text { NCTC } & 8309 \\ \text { Str. faecalis } & \text { NCTC } & 8213\end{array}$

\section{Pooled Urine}

Urine was collected over 24 hours from five healthy males aged 25-50 years, pooled and mixed well prior to filtration through a 'Millipore' filter ( 0.22 microns). Sterility was tested by culturing $0.1 \mathrm{ml}$ of pooled urine using standard methods. the males supplying the urine samples had no medications, were on an unrestricted diet and had a full urine analysis prior to the collection of the 24 hour samples. The $\mathrm{pH}$ of the pooled urine was $6 \cdot 0-6 \cdot 4$.

\section{Inoculum}

All strains of bacteria were grown at $37^{\circ} \mathrm{C}$ in the vehicle used for testing on the day prior to experiments except distilled water and saline. One hundred mls of the vehicle were then inoculated with $0.1 \mathrm{ml}$ of the over-night culture and shaken in the water bath for 2 hours prior to addition of the test mixtures.

\section{Viable Counts}

Viable counts were performed just prior to the addition of the test solutions and 
thereafter at hourly intervals for six hours. This time was chosen because in hospitals bladder instillation solutions are usually changed every six hours during intermittent catheterisation procedures.

For each count three sets of Io-fold dilutions were made and $0.1 \mathrm{ml}$ of each dilution spread on to air dried nutrient agar plates and incubated for 24 hours at $37^{\circ} \mathrm{C}$. All experiments were performed at least three times in each vehicle and the mean values recorded. When pooled urine was used each experiment was repeated on at least three separate urine collections. Lubrol broth was used as the diluent for viable counts on mixtures containing chlorhexidine. Similarly EDTA was neutralised with saline.

In the schematic figures the initial colony count is recorded as $10^{\circ}$ (usually $10^{7}-10^{8}$ orgs $/ \mathrm{ml}$ ) and subsequent values recorded as the log of the difference to the initial count. When the dilution gave a value of $>\mathrm{IO}^{-7}$ no organisms were detectable on the viable count plates.

\section{Results}

As expected Ps. aeruginosa grew in nutrient broth (NB), urine (UR) and minimal media (MM) but not in saline (SA) or distilled water (DW) (Fig. I). When ETDA (500 mg/l) was added to each of the vehicles the viable count was reduced in MM and DW (Fig. 2). The addition of $0.05 \mathrm{M}$ Tris alone reduced the viability of Pseudomonas slightly in all vehicles except in NB (Fig. 3). However when EDTA was used in conjucntion with Tris the killing effect was most marked in the case of DW and gradually decreased in effectiveness in the other vehicles (Fig. 4).

Chlorhexidine rapidly killed Pseudomonas in DW, SA, and MM. In NB the organism was reduced far less rapidly and in UR the organism started to re-grow after showing an initial reduction in viability (Fig. 5).

The experiments demonstrated that of all the vehicles used, pooled urine was the most inhibitory to the agents tested. Consequently in order

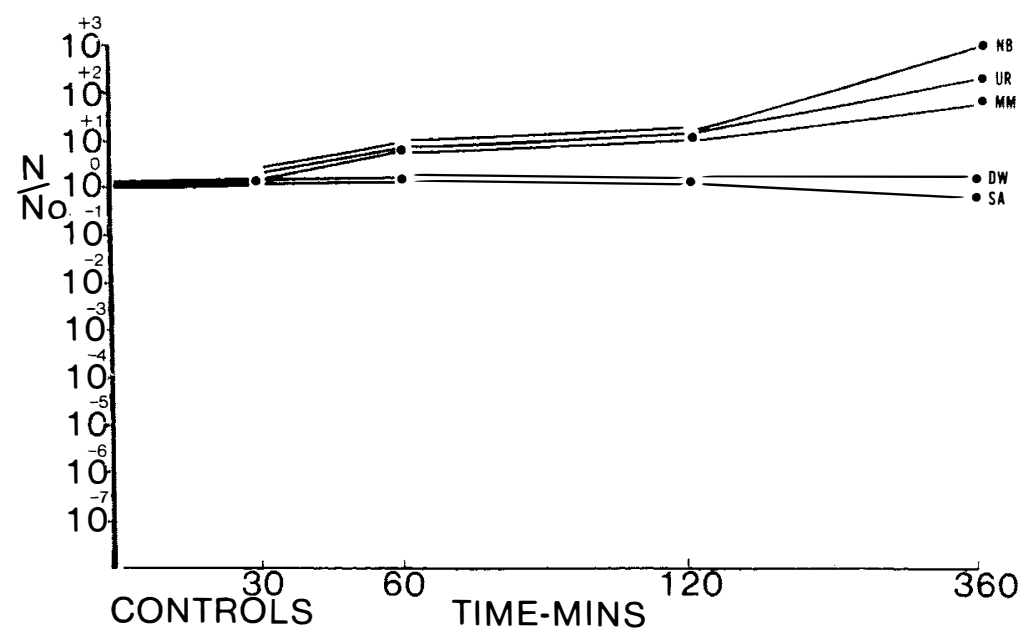

FIG. I

The effect of instillation solutions on the viability of Ps. aeruginosa in different vehicles. D.W. = Distilled water; S.A. = Saline; M.M. = Minimal medium; N.B. = Nutrient broth; U.R. = Pooled urine. 


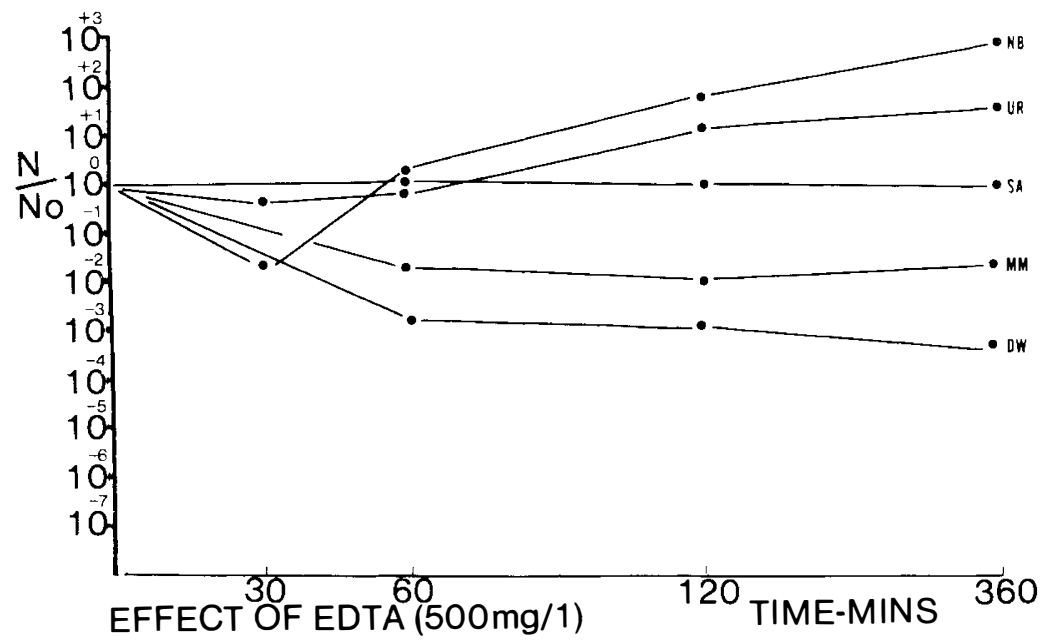

FIG. 2

The effect of instillation solutions on the viability of Ps. aeruginosa in different vehicles. D.W. = Distilled water; S.A. = Saline; M.M. = Minimal medium; N.B. = Nutrient broth; U.R. = Pooled urine.

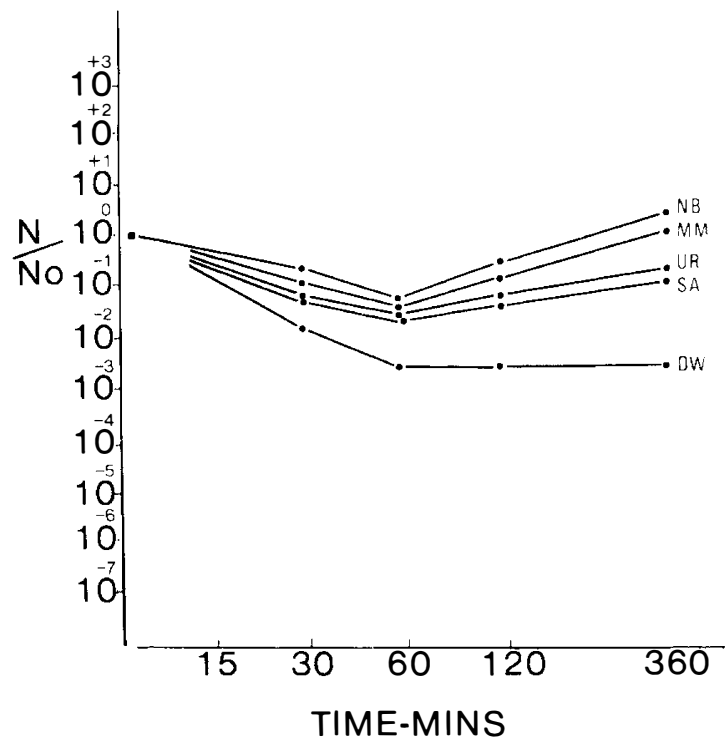

FIG. 3

Effect of Tris $(0.05 \mathrm{~m})$

D.W. = Distilled water; S.A. = Saline; U.R. = Pooled urine; M.M. = Minimal medium; N.B. $=$ Nutrient broth.

to simulate some of the in vivo conditions, pooled urine was used in all further tests. In the presence of EDTA or Tris, the concentrations of chlorhexidine tested only improved its killing action slightly (Fig. 6). 
90

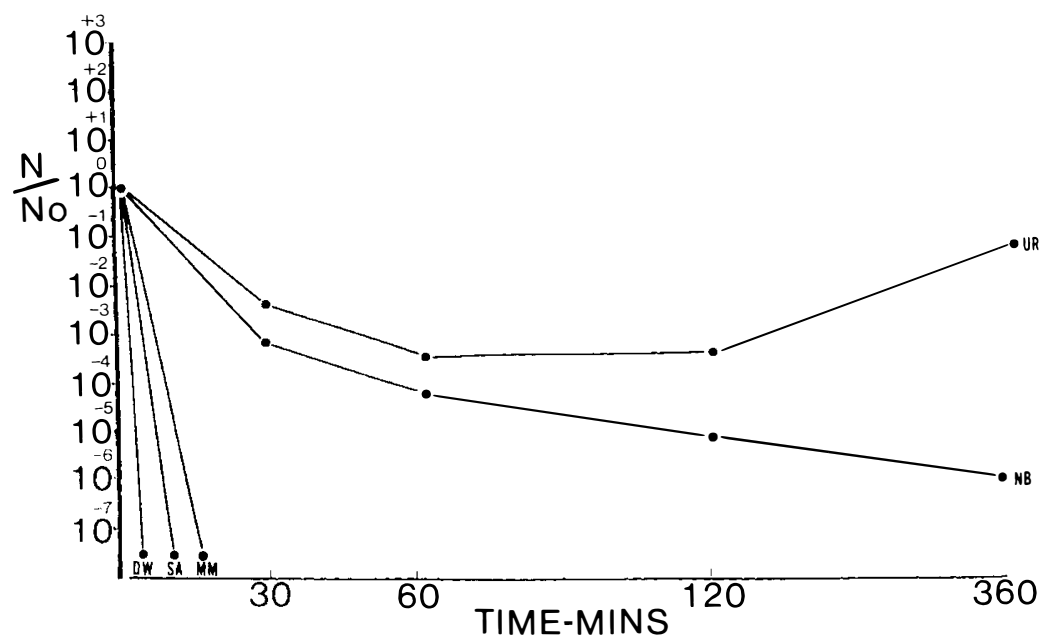

FIG. 4

Effect of different vehicles on the action of chlorhexidine $\left(\mathrm{O} \cdot \mathrm{OI}^{\circ}{ }_{0}\right)$ against - Ps. aeruginosa. D.W. = Distilled water; S.A. = Saline; M.M. = Minimal medium; N.B. = Nutrient broth; U.R. = Pooled urine.

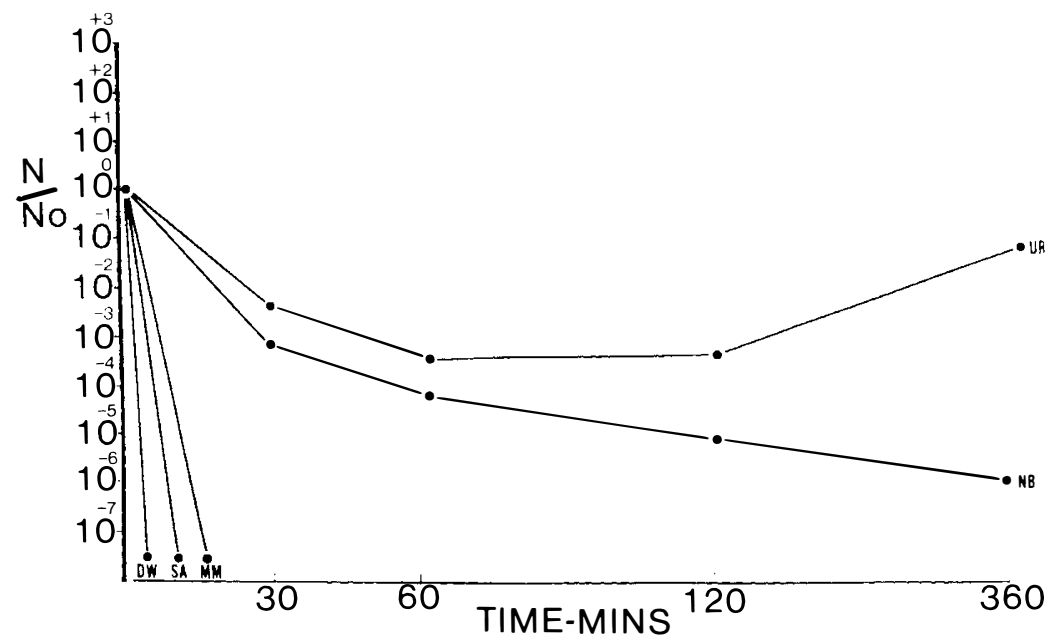

FIG. 5

Effect of different vehicles on the action of chlorhexidine $\left(\mathrm{O}^{\circ} \mathrm{OI}^{\circ}{ }_{0}\right)$ against - Ps. aeruginosa. D.W. = Distilled water; S.A. $=$ Saline; M.M. $=$ Minimal medium; N.B. $=$ Nutrient broth; U.R. $=$ Pooled urine.

However the full combination of EDTA/Tris and chlorhexidine resulted in rapid killing of Pseudomonas even in the presence of pooled urine. (Fig. 6). Similar results were obtained when chlorhexidine/EDTA/Tris was tested on E. coli P. mirabilis and Strep. faecalis (Fig. 7).

\section{Discussion}

The purpose of any in vitro testing of an antibacterial bladder instillation 


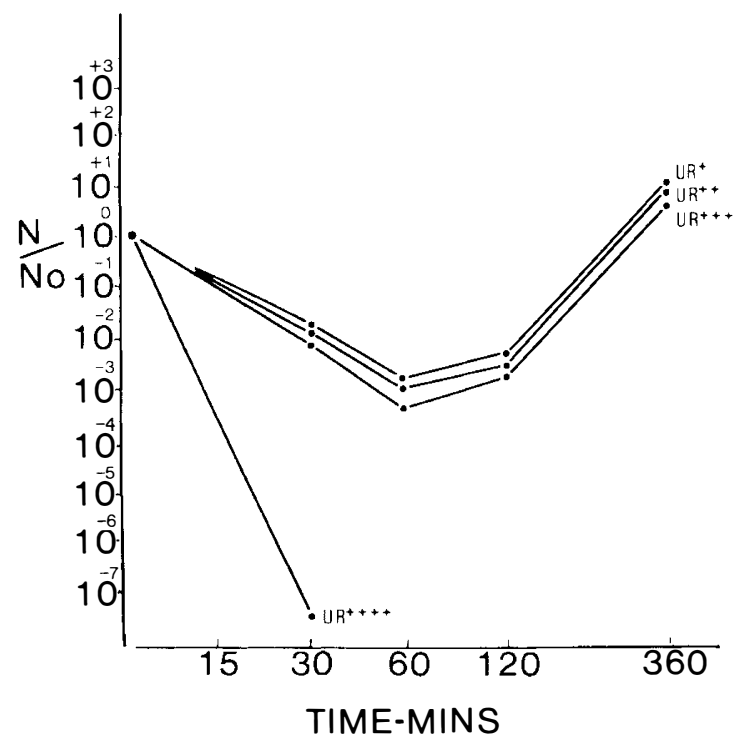

FIG. 6

$\mathrm{UR}^{+} \quad$ Chlorhexidine $\left(0 \cdot 0 \mathrm{I}^{\circ}{ }_{0}\right)$ EDTA (500 mg).

$\mathrm{UR}^{++}$Chlorhexidine $\left(0.0 \mathrm{I}^{\circ}{ }_{0}\right)$ Tris $(0.05 \mathrm{M})$.

$\mathrm{UR}^{+++}$Chlorhexidine $\left(0 \cdot 2^{\circ}{ }_{0}\right)$ EDTA $(500 \mathrm{mg})$.

$\mathrm{UR}^{++++}$Chlorhexidine $\left(\mathrm{O} \cdot \mathrm{I}^{\prime \prime}{ }_{0}\right)$ EDTA $(500 \mathrm{mg})$ Tris $(0.05 \mathrm{M})$.

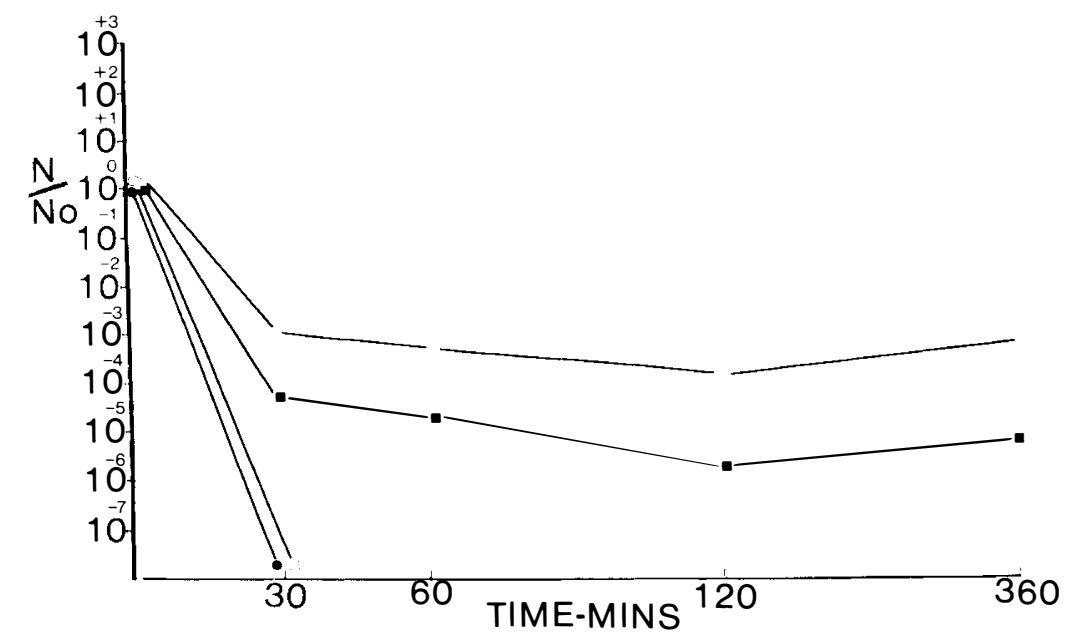

FIG. 7

Effect of chlorhexidine $\left(0.0 \mathrm{I}^{\circ}{ }_{0}\right)$ EDTA $(500 \mathrm{mg} / \mathrm{l})$ Tris buffer $(0.05 \mathrm{M})$ in pooled urine on $\square$ E. coli, $\bullet$ Ps. aeruginosa, $\square$. mirabilis and $\bigcirc$ Strep. faecalis.

solution is to assess its possible efficacy for application in vivo. For this reason pooled urine was investigated as a vehicle for testing the antimicrobial effect of a bladder rinse solution. In general it was found that the solutions tested were less effective in urine than in other vehicles. This indicates that the in vitro tests that have been performed in other vehicles are 
probably not a true indication of the efficacy of chlorhexidine and could be relevant to other antimicrobial solutions used as bladder rinse solutions.

The addition of EDTA/Tris buffer to chlorhexidine appears to enhance the antiseptic action even in the presence of urine. As the composition of urine may vary with fluid intake and other factors, urine pooled from different individuals was used in order to minimise some of these variables. The replicate experiments with different batches of pooled urine gave similar results suggesting that these variables did not have a significant effect on the results. Other factors such as leucocytes, cellular and organic debris, found in infected urine which can reduce the activity of antiseptics should also be considered.

The strain of Ps. aeruginosa used appeared less sensitive to EDTA than was expected from previous reports on this species (Voss, 1967). This may be due to the different experimental conditions and/or the strain of bacteria used. Consequently, it is considered that the methods employed in this study are stringent for evaluating bladder instillation solutions. Although similar results were obtained with $E$. coli and $P$. mirabilis the solutions were less effective with Strep. faecalis. This may be due to the structure of the Gram-positive cell wall, for example the higher techoic acid content (Cutinelli, 1967). Although only one strain of each species has been tested in this present study, the results demonstrate the need to duplicate as far as possible in vivo conditions when performing in vitro tests on bladder instillation solutions. The conditions of the test procedure used are not an exact model of the intermittent catheterised bladder which has urine continuously flowing into it and can cause dilution of the antiseptic, further reducing its effect.

Using a physical model of the bladder such as that described by Greenwood and O'Grady (1975) with pooled urine as the medium might lead to further useful information as to the frequency and duration of instillation solutions required over a 6 hourly period.

Investigations of combinations of chelating agents for Gram-positive and Gram-negative bacteria should be further explored. Their use in alternated six hourly combinations could possibly give wider cover against the different species found in UTIs. Bathing in similar antiseptic mixtures by patients colonised with multiple antibiotic resistant bacteria may also prove useful. This procedure may be helpful in either decolonising the patients skin and/or help to control the spread of these organisms throughout the hospital environment.

\section{RÉSUMÉ}

La concentration de chlorhexidine digluconate qui est nécessaire pour tuer les bactéries Gram-négatives, une cause de l'infection des voies urinaires qui est associée avec le cathétérisme urétral, a l'effet d'endommager la muqueuse vésicale aussi. Une augmentation de l'activité bactéricide a été obtenue par l'addition d'un agent de chélation (EDTA) et une solution tampon (TRIS), ce qui a permis une faible concentration de chlorhexidine (0.01\%) d'agir contre Escherichia coli NCTC 86, Pseudomonas aeruginosa NCTC 6750, Proteus mirabilis NCTC 8309 et Streptococcus faecalis NCTC 8213. Le type de fluide dans lequel les bactéries ont été suspendues a affecté le temps nécessaire pour obtenir une extermination de $99.9 \%$. La solution de $0.01 \%$ de chlorhexidine avec l'addition de EDTA et de TRIS n'a pas causé une érosion sévère de la muqueuse vésicale des rates. Nous avons considéré le potentiel de l'emploi de cette solution comme un antiseptique pour la peau avant le cathétérisme, et comme une instillation dans la vessie après le cathétérisme. 


\section{ZUSAMMENFASSUNG}

Die Konzentration von Chlorhexidine Digluconate die gebraucht wird um die gramnegative Bakteria zu töten, die Ursache sind von der Urinary Tract Infektion und verbunden mit einer Schädigung der Blasenschleimhaut. Vergrösserte baktericidal Aktivität wurde errungen bei der Zufügung von einer chelating wirkender Kraft und einem Prellbock (tris) ermöglicht eine niedrige konzentration von Chlorhexidine $(0.01 \%)$ wirksam zu sein gegen Escherichia coli NCTC 86, Pseudomonas aeruginosa NCTC 6750, Proteus mirabilis NCTC 8309 und Streptococcus faecalis NCTC 8213. Der Typ von Flüssigkeit in welcher die Bakteria schwebte, beeindrückte die Zeit die gebraucht wurde um $99.9 \%$ erfolgreich zu sein. Die $0 . \mathrm{OI}^{\circ}{ }_{\circ}$. Chlorhexidine Auflösung mit Zusatz von edta und tris gründete keinen schweren zersetzenden Schaden an der Blasenschleimhaut bei Ratten. Die Leistungsfähigkeit dieser auf Lösung zur Benützung als ein antiseptisches Hautmittel vor der Catheterisation und als eine Blaseneintropfung nach der Catheterisation wird besprochen.

Acknowledgements: I would like to thank $\mathrm{Dr} \mathrm{W}$. Grubb for his critical suggestions and help, also Mr J. Epis for technical assistance and Miss J. Payne for typing the manuscript.

\section{REFERENCES}

Beeuweeks, H. \& DE VRIES, H. R. (1956). Chlorhexidine in Urology. Lancet, 2, 913914.

BRown, M. R. W. \& RichaRds, R. M. W. (1965). Effect of ethylene diamine tetraacetate on the resistance of Pseudomonas aeruginosa to antibacterial agents. Nature, 207, I 39 I-I 393.

Caplin, H. \& Chapman, D. C. (I976). A comparison of three commercially available antiseptics against opportunist Gram-negative pathogens. Microbios., I6, I33-137.

Cutinelli, C. \& Galdiero, F. (I967). Ion binding properties of the cell wall of Staphylococcus. F. Bact., 93, 2022.

Gillespir, W. A., Lennon, G. G., Linton, K. B. \& Slade, N. (1962). Prevention of catheter infection of urine in female patients. Brit. Med. F., 2, 13-16.

Goldschmidt, M. C., Kuhn, C. R., Perry, K. \& Johnson, D. E. (I972). EDTA and lysozyme lavage in the treatment of Pseudomonas and coliform bladder infections. F. Urol. (Baltimore) 107, 969-972.

GoldschmidT, M. C. \& Wyss, O. (1967). The Role of Tris in EDTA toxicity and lysozyme lysis. F. Gen. Microbiol., 47, 42 I-430.

GREENWOOD, D. \& O'GRADY, F. (I975). Response of ampicillin resistant escherichia coli to cephalorins in an in vitro model simulating conditions of bacterial growth in the urinary bladder. Brit. F. exp. Path., 56, I67-I7I.

HARPER, W. E. S. \& MATZ, L. T. (1976). Further studies on effects of irrigation solutions on rat bladders. Brit. F. Urol., 47, 463-467.

Lindan, R. (1972). Sources of Urinary Sepsis in Urethral Catheterization. Paper read at Symposium International Sobre Infection del Tracto Urinario. Jimenex Diaz Foundation, Madrid, Spain, November.

MaCFADYEN, I. R. \& Simmons, S. C. (I 968). Urinary infection after colporrhaphy: Its incidence causation and prevention. F. Obstet. Gynaec. Brit. Cwlth, 75, 87I-875.

Paterson, M. L., BarR, W. \& MACDonald, S. (I960). Urinary infection after colporrhaphy: Its incidence causation and prevention. f. Obstet. Gynaec. Brit. Cwlth., 76, 394-401.

Pearman, J. W. (I97I). Prevention of urinary tract infection. Following spinal cord injury. Paraplegia, 9, 95-104.

Pearman, J. W. (I977). Reducing the Risk of Bacteriuria from Indwelling Catheters. (Published in Abstracts of Proceedings) read at Australian Society for Microbiology Annual Scientific Meeting, Melbourne. I 7-20 May.

Stickler, D. J. (1974). Chlorhexidine resistance in Proteus mirabilis. F. of Clin. Path., 27, 284-287.

Voss, J. G. (1967). Effects of organic cations on the Gram-negative cell wall and their bactericidal activity with Ethylenediaminetetra-acetate and surface active agents. f. Gen. Microbiol., 48, 39I-400. 